\title{
Fiduciāro aktīvu pārvaldes līgums jaunajā Ungārijas Civilkodeksā
}

\author{
Jānis Grasis \\ Rìgas Stradiṇa universitāte, Juridiskā fakultāte, \\ Tiesību zinātṇu katedra, Latvija \\ Janis.Grasis@rsu.lv
}

\section{Kopsavilkums}

Autors rakstā aplūko jaunu līguma veidu, kas tika iekḷauts nesen pien,emtajā Ungārijas Civilkodeksā, - fiduciāro aktīvu pārvaldes līgumu. Sekojot Čehijas Republikas piemēram, Ungārija ir otrā valsts Austrumeiropā, kas ir pārṇēmusi trasta instrumentu savās materiālajās tiesībās. Rakstā tiek apskatīta fiduciāro aktīvu pārvaldes līguma būtība, fiduciāro aktīvu pārvaldīšana un izbeigšana.

Atslēgvārdi: Ungārijas Civilkodekss, trasts, fiduciārais īpašums, fiduciāro aktīvu pārvaldnieks.

No brīža, kad šī raksta autors aizstāvēja savu disertāciju par trastiem, jau ir pagājuši astoṇi gadi. Kopš tā laika daudz kas ir mainījies finanšu un trastu pasaulē. Toreiz privātās komercbankas un zvērināti advokāti bija ḷoti ieinteresēti trasta likuma ieviešanā Latvijā, taču finanšu krīze 2008. un 2009. gadā ieviesa savas korekcijas. Privātajām komercbankām nācās lielu uzmanību veltīt finanšu krīzes problēmām, un trasta lietas tika atliktas. Bet pa šiem gadiem divas Austrumeiropas valstis - Čehija un Ungārija ir ieviesušas trasta instrumentu savā tiesību sistēmā. Jāpiebilst, ka tās abas ir OECD* dalībvalstis, kas nozīmē, ka OECD principā nav pret trasta instrumentu kā tādu. Par Čehijas jauno likumu šo rindu autors jau ir publicējis rakstu [4]. Šajā Socrates numurā tiks aplūkots Ungārijas jaunais regulējums.

* OECD - Organization for Economical Cooperation and Development (Ekonomiskās sadarbības un attīstības organizācija). Latvijas Republika pievienojās šai organizācijai 2016. gada 1. jūlijā. 
Jaunais Ungārijas Civilkodekss (2013. gada likums Nr. V; turpmāk tekstā - Civilkodekss) stājās spēkā 2014. gada 15. martā [1]. Civilkodeksa XLII nodaḷa nosaka Fiduciāro aktīvu pārvaldes līguma (Bizalmi vagyonkezelési szerződés - ungāru valodā) tiesisko regulējumu, kas balstās uz aǵenta līguma parauga. Šĩ Ungārijai jaunā līguma koncepcija balstās uz trasta modeliem, kas pastāv anglosakšu tiesībās, un Treuhand institūtu Vācijā [5]. Savulaik lords Brouns-Vilkinsons saistībā ar trasta tiesisko dabu un taisnīguma interesēm anglosakšu tiesībās XX gadsimtā apkopoja galvenās fundamentālās atziṇas tiesas lēmumā Westdeutche Landesbank Girozentrale vs. Islington Borough Council [7]:

i) Taisnīgums ietekmē juridiskā īpašnieka sirdsapziṇu. Trasta gadījumā juridiskā ipašnieka sirdsapziṇa pieprasa no viņa īstenot mērķus, kuru dēḷ īpašums tika nodots viņam (izteikuma vai netiešais trasts) vai kurus uzliek viṇam likums bezkaunīgas uzvedības gadījumā (konstruktīvais trasts);

ii) Tā kā taisnīguma jurisdikcijas piemērošana trastam ir atkarīga no juridiskā ìpašnieka sirdsapziņas, tad viņš nevar būt par īpašuma pārvaldnieku tik ilgi, kamēr viņš noliedz faktus, kas ietekmē viṇa sirdsapziṇu;

iii) Lai izveidotu trastu, ir nepieciešams identificējams trasta īpašums. Vienīgais neapšaubāmais izṇēmums šim likumam ir konstruktīvais trasts, kas tiek uzspiests personai, kura negodīgi palīdz trasta pārkāpumā un kurai iestājas fiduciāri pienākumi pat tad, ja tā nesaṇem identificējamu trasta īpašumu;

iv) Ja trasts ir izveidots, tad no tā nodibināšanas dienas labuma guvējam pēc taisnīguma ir īpašnieka intereses pret trasta īpašumu, kuras ir realizējamas pret jebkuru îpašuma (sākotnējo īpašumu vai aizstājošo îpašumu, kam var izsekot) valdītāju, kas nav juridiski pircējs [3].

Fiduciārā uzticība (Treuhand) [5] Vācijā tiek nodibināta, nododot aktīvus fiduciāram un papildus noslēdzot līgumisku vienošanos par iespējamo samaksu fiduciāram un fiduciāra pienākumus aktīvu pārvaldīšanā par labu labuma guvējiem. Parasti dibinātājs un fiduciārs vienojas, ka labuma guvējiem ir tiesības celt tieši prasību pret fiduciāru. Tomēr šìs tiesības ir jāuzskata par parastajām tiesībām in personām noslēgtās vienošanās ietvaros, bet ne prasība ius in re aliena. Fiduciāra pienākumi Vācijā ir uzskatāmi par klasiskiem pienākumiem kopš Senās Romas laikiem, vai tie ir atrunāti fiduciārajā līgumā, vai noteikti ar tiesas uzliktajiem pienākumiem; jebkurā gadỉjumā fiduciāram ir:

1) jāizvairās no interešu konfliktiem;

2) jātur šḳirti no savas personiskās mantas fiduciārās uzticības aktīvi;

3) jāuztur skaidri un precīzi pārskati par aktīvu pārvaldīšanu;

4) jālauj dibinātājam vai labuma guvējiem iepazîties ar pārskatiem;

5) jātur atsevišḳi no saviem naudas līdzekḷiem bankās fiduciārās uzticības naudas līdzeklıi;

6) jāatskaitās par gūto peḷnu aktīvu pārvaldī̌sanā;

7) jābūt uzticamam, jāievēro labas ticības princips utt.

Ja fiduciārs neizpilda savus pienākumus, tad labuma guvēji var celt personisku prasību par nodarìtajiem zaudējumiem [5]. 
Nepieciešamību ieviest fiduciāro aktīvu pārvaldes līgumu Ungārijas tiesībās noteica pieprasījums ekonomikā, jo tika konstatēts, ka investori Ungārijā izvēlas veidot trastus citās jurisdikcijās tāpēc, ka tas nodrošina labākus juridiskos un ekonomiskos risinājumus [6].

Protams, galvenais jautājums ir, vai Ungārijas trasta institūts ir analogs tam trastam, ko mēs saprotam ar trastu anglosakšu tiesībās. Tādējādi galvenie izpētes jautājumi ir trasta aktīvu îpašumtiesības, šo aktīvu nodalīšana no trasta dibinātāja un fiduciāra aktīviem, iesaistīto pušu tiesības, iespējas atgūt trasta aktīvus, prasības trasta pārvaldniekam, trasta līguma ilgums.

Civilkodeksa 6: 310. pantā tiek dota fiduciāro aktīvu pārvaldes līguma definīcija. Saskaṇā ar to fiduciārs uzṇemas savā vārdā pārvaldìt aktīvus, tiesības un saṇemamo labumu (turpmāk tekstā - pārvaldāmie aktīvi), ko viņam pieškịiris trasta dibinātājs", par labu labuma guvējam, un trasta dibinātājs apn,emas samaksāt atrunāto samaksu. Līgums ir jānoslēdz rakstveidā. Savukārt 6: 312. pants strikti nosaka, ka pārvaldāmie aktīvi nedrīkst tikt sajaukti ar fiduciāra personīgajiem aktīviem vai citiem aktīiem, ko viṇš pārvalda, un fiduciāram atsevišḳi jāuzskaita pārvaldāmie aktīvi. Jebkura cita vienošanās nav spēkā. Pārvaldāmo aktīvu sastāvdaḷas, kas tiek turētas atsevišḳi no fiduciāra aktīviem un citiem pārvaldāmiem aktīviem un tiek norādītas kā pārvaldāmie aktīvi, tiks uzskatītas par pārvaldāmajiem aktīviem, ja vien nav pierādīts pretējais. Fiduciāra personīgie aktīvi, kas netiek atspoguḷoti kā pārvaldāmie aktīvi, tiks uzskatīti par fiduciāra personīgajiem aktīviem, ja vien nav pierādīts pretējais. Pārvaldāmo aktīvu aizsardzība ir noteikta 6: 313. pantā. Ne fiduciāra laulātajam vai mājsaimniecības partnerim, ne personīgajiem kreditoriem vai fiduciāra citu pārvaldāmo aktīvu kreditoriem nav tiesību vērst prasību pret jebkuriem pārvaldāmajiem aktīviem. Gan labuma guvējam, gan trasta dibinātājam ir tiesības celt prasību pret fiduciāra laulāto vai mājsaimniecības partneri, fiduciāra personīgajiem kreditoriem vai fiduciāra citu pārvaldāmo aktīvu kreditoriem, lai tiktu nošķirti atsevišḳi pārvaldāmie aktīvi.

Labuma guvēja un to kreditoru tiesības tiek atrunātas Civilkodeksa 6: 314. pantā. Labuma guvējam ir tiesības izprasìt no fiduciāra pārvaldāmos aktīvus un ienākumus no tiem saskaṇā ar noslēgto līgumu. Savukārt labuma guvēja kreditori ir tiesīgi celt prasỉjumu pret pārvaldītajiem aktīviem tikai no brīža, kad minētie aktīvi vai ienākums no tiem tiek nodots labuma guvējam. Gan trasta dibinātājs, gan labuma guvējs ir tiesīgi pārbaudīt fiduciāra veiktās darbības saistībā ar pārvaldāmajiem aktīviem. Pārbaudes izmaksas sedz trasta dibinātājs vai labuma guvējs saskaṇā ar Civilkodeksa 6: 315. pantu. Civilkodeksa 6: 316. pants stingri noteic, ka nedz trasta dibinātājs, nedz labuma guvējs nevar dot nekādus rīkojumus fiduciāram; jebkuri pretēji noteikumi nav spēkā esoši.

* Lai arī Ungārijas Civilkodeksa angḷu valodas versijā trasta dibinātāja apzīmēšanai tiek lietots termins the principal, ko parasti latviešu valodā tulko vienkārši kā "principāls", tomēr autors dod priekšroku klasiskajai terminologijai, kas saistīta ar trastiem. 
Fiduciāra galvenie uzdevumi un pienākumi ir noteikti Civilkodeksa 6: 317. pantā un turpmākajos pantos. Fiduciāra galvenais pienākums ir rīkoties pēc iespējas labāk labuma guvēja interesēs, kas izriet no uzticības attiecībām. Ievērojot saprātīgu komerciālo praksi, fiduciāram ir pienākums pasargāt pārvaldāmos aktīvus no paredzamiem riskiem. Fiduciāram aktīvu pārvaldīšana ir jāveic tā, lai varētu nosegt jebkuras saistības, kas izriet no pārvaldāmajiem aktīviem. Fiduciāram ir tiesības veikt aktīvu izvietošanu saskaṇā ar līgumā noteiktajiem nosacỉjumiem un limitiem. Ja fiduciārs to pārkāpj un nelikumīgi atsavina pārvaldāmos aktīvus trešajai personai, trasta dibinātājam un labuma guvējam ir tiesības atgūt šādus aktīvus un tos atjaunot starp pārvaldāmajiem aktīviem, ja trešā persona nav rīkojusies labā ticībā. Šis noteikums attiecas arī uz gadījumiem, kad pārvaldāmie aktīvi ir kḷūdas pēc apgrūtināti.

Civilkodeksa 6: 321. pants nosaka fiduciāra atbildību trasta dibinātāja un labuma guvēja priekšā. Saskaṇā ar panta pirmo daḷu fiduciārs atbild par savu pienākumu pārkāpšanu gan trasta dibinātājam, gan labuma guvējam saskaṇā ar Ungārijas Civilkodeksa vispārējiem noteikumiem par saistību neizpildīšanu. Neko nemaina situācija, ja fiduciārs nav saṇēmis atlīdzību par veiktajiem pienākumiem. Savukārt 6: 321. panta trešā daḷa nosaka, ka gan trasta dibinātājam, gan labuma guvējam ir tiesības celt prasību pret fiduciāru par jebkuru finansiālu labumu, ko tas ir guvis, pārkāpjot savus pienākumus, un šādu finansiālu labumu pēc tam var pievienot kopējiem pārvaldāmajiem aktīviem.

Civilkodeksa 6: 326. pantā uzskaitīti četri gadījumi, kad fiduciārais aktīvu pārvaldes līgums tiek izbeigts:

1) vairs nav aktīvu, ko pārvaldīt;

2) trīs mēnešu laikā kopš brīža, kad fiduciārs paziṇo par atkāpšanos;

3) nav neviena fiduciāra, kas pārvaldìtu aktīvus vairāk nekā trīs mēnešus no brīža, kad ir beidzies fiduciāra pilnvaru termiņš;

4) trasta dibinātāja nāves gadījumā, ja viṇš bija vienīgais labuma guvējs.

Ja fiduciārs atkāpjas no amata, tad viṇa galvenais uzdevums ir darīt visu iespējamo, kas ir labuma guvēja interesēs. Līdzīgi kā anglosakšu tiesībās, fiduciārā aktīvu pārvaldes līguma maksimālais termiņš ir piecdesmit gadu; ja līgumā noteikts citādi, šāds punkts nav spēkā. Fiduciārais aktīvu pārvaldes līgums netiek izbeigts gadījumā, ja trasta dibinātājs kḷūst par fiduciāra mantinieku; tāpat tas netiek izbeigts trasta dibinātāja, fiduciāra vai labuma guvēja nāves vai likvidācijas gadījumā (ja tie ir juridiskas personas).

Kopumā Ungārijas jaunais regulējums atbilst anglosakšu trastam un Treuhand regulējumam Vācijā. Tomēr ir arī dažas atšḳirības, ja mēs salīdzinām Ungārijas trasta versiju un anglosakšu tiesības. Ungārijas Civilkodeksā fiduciāro aktīvu pārvaldes līgums visvairāk līdzinās skaidri izteiktajam trastam* [3, 13]. Prezumējošais trasts** var izveidoties tikai izṇēmuma gadỉjumos (6: 321.(3) pants); vienlaikus Ungārijā netiek regulēts

* Skaidri izteiktais trasts, angḷ val. - express trust.

** Prezumējošais trasts, anglu val. - resulting trust. 
konstruktīvais un labdarības trasts. Fiduciāro aktīvu pārvaldes līgums ir jānoformē rakstveidā, savukārt anglosakšu tiesībās trastu var radīt mutvārdos vai ar noteiktām darbībām. Ungārijā fiduciārs par sniegtajiem pakalpojumiem saṇem atlīdzību, savukārt anglosakšu tiesībās trasta pārvaldniekam kā vispārējais noteikums ir veikt pienākumus bez maksas, ja vien atlīdzïba nav pielīgta.

\section{Secinājumi}

Ungārijas jaunievedums - fiduciāro aktīvu pārvaldes līgums - vēlreiz pierāda, ka nav tiesisku problēmu pārṇemt romāṇu germāṇu tiesību saimes valstīs anglosakšu trastu. Arī Lat vijā ir jāatgriežas pie diskusijas par trasta instrumenta pārṇemšanu materiālajās tiesībās.

\section{Fiduciary Asset Managament Contract in the New Civil Code of Hungary}

\section{Abstract}

The author briefly reviews the new type of contract - fiduciary asset management contract, which was introduced recently in the new Civil code of Hungary. Following the Czech Republic, Hungary is the second country in Eastern Europe, which has introduced trust instruments in internal material law. The esence of the fiduciary asset management contract, management of the fiduciary assets and termination of it is discussed.

Keywords: Civil Code of Hungary, trust, fiduciary property, fiduciary.

\section{Literatūra}

1. Act V of 2013 on the Civil Code. Iegūts no: https://tdziegler.files.wordpress.com/2014/06/ civil_code.pdf [sk.14.10.2016].

2. Balodis, K. Fiduciāro darījumu vieta Latvijas privāttiesību sistēmā. Likums un Tiesības. 2005, 9, 271. lpp.

3. Edwards, R. \& Stockwell, N. Trusts and Equity. Sixth edition. Person Longman, 2004, p. 9.

4. Grasis, J. Trust Regulation in the Czech Republic: the Model Law for Introduction of the Trust Instrument in the Republic of Latvia? EIRP Proceedings. 11, 2016, p. 50-59.

5. Kötz, H. National Report for Germany. Principles of European Trust Law. D. J. Hayton, S. C. J. J. Kortmann, H. L. E. Verhagen (eds.). Kluwer Law International - W. E. J. Tjeenk Willink, 1999, p. 89.

6. Sandor, I. The New Hungarian Fiduciary Asset Management Contract (Trust) from Comparative Aspect. US - China Law Review. Vol. 12: 600, p. 604.

7. Westdeutsche Landesbank Girozentrale v Islington Borough Council [1996] 2 All ER 961. Iegūts no: https://www.lawteacher.net/free-law-essays/restitution-law/english-law-of-restitution.php [sk.14.10.2016.]. 